\title{
Sound production and reception in mangrove crabs Perisesarma spp. (Brachyura: Sesarmidae)
}

\author{
P. Y. Boon*, D. C. J. Yeo, P. A. Todd \\ Department of Biological Sciences, Marine Biology Laboratory, National University of Singapore, 14 Science Drive 4, Blk S1, \\ \#02-05, Singapore, 117543
}

\begin{abstract}
Acoustic signalling and sound production structures in the sesarmid crabs Perisesarma eumolpe (De Man) and $P$. indiarum (Tweedie) from Mandai mangroves, Singapore, were examined using 40 to $20000 \mathrm{~Hz}$ sound recordings and scanning electron microscopy. The sound receptor, Barth's myochordotonal organ, was identified in both species. Only male crabs were found to display acoustically, and only during agonistic interactions. The present study also revealed key speciesspecific differences in the morphology of the stridulatory organs, stridulatory movements and resulting sounds produced. The findings show that acoustic signalling may be a significant component in the social behaviour of mangrove sesarmid crabs.
\end{abstract}

KEY WORDS: Sound $\cdot$ Mangroves $\cdot$ Crab $\cdot$ Crustacea $\cdot$ Brachyura $\cdot$ Sesarmidae $\cdot$ Perisesarma spp. Stridulation $\cdot$ Singapore

Resale or republication not permitted without written consent of the publisher

\section{INTRODUCTION}

Relatively little research has been conducted on the social interactions of mangrove-dwelling sesarmid crabs (Mulstay 1980, Seiple \& Salmon 1982), despite their important ecological role in this habitat (Smith et al. 1991, Lee 1998). In the only detailed study of sesarmid social behavior to date, Seiple \& Salmon (1982) found that Sesarma reticulatum has more elaborate territorial systems and longer and more aggressive agonistic encounters compared to $S$. cinereum, which spends more time on courtship. The complexity of the social behaviour in these sesarmids suggests that some form of intricate communication system exists (Seiple \& Salmon 1982). Although the emphasis of studies on grapsoid crab (including sesarmids) communication has been on visual displays (Schöne 1968, Huang et al. 2008), given their gregarious nature and the presence of potentially sound-producing morphological structures in many species (Guinot-Dumortier \& Dumortier 1960), the use of acoustic signals may be expected.

Semiterrestrial crabs produce sound by a number of methods (von Hagen 1975): (1) respiration, the movement of fluid across an orifice; (2) convulsion, the free vibration or quivering of appendages; (3) percussion or rapping, the striking of a body part on the substrate; and (4) stridulation or rasping, a file-and-scraper mechanism involving the appendages and/or the cephalothorax (Guinot-Dumortier \& Dumortier 1960, Salmon \& Horch 1972) where the file (pars stridens), a surface of ridges or tubercles, is rubbed against a scraper (plectrum), which may be a protrusion with a tapering edge or a line of denticulations (Dumortier 1963, Clayton 2005). In general, it is the plectrum that moves against the pars stridens, but the inverse is not uncommon (Guinot-Dumortier \& Dumortier 1960). Rapping and rasping are the most common modes of sound production in acoustic signalling in crabs.

Most studies on acoustic communication in brachyurans have focused on ocypodid crabs (e.g. Horch \& Salmon 1969, Salmon \& Horch 1972, Budelmann 1992), specifically, ghost crabs (e.g. Horch 1971, 1975, Clayton 2001) and fiddler crabs (e.g. Salmon 1965, 1967, Crane 1966, Salmon \& Atsaides 1968). Much less is known about the Sesarmidae. The presence of ridges on the chelipeds of sesarmids were previously reported (Guinot-Dumortier \& Dumortier 1960), but any possible stridulatory function was dismissed due to 
doubts regarding the plausibility of reciprocal rubbing of the chelipeds (Ortmann 1901). However, rasping was subsequently reported in Sesarma reticulatum by Seiple \& Salmon (1982, p. 6) who described it as 'self tapping' in which 'one claw [is] raised and brought down to make contact with the dorsal surface of the manus of the other claw'. Mulstay (1980) provided similar descriptions of a stationary claw being struck by a moving one, but referred to it as rapping. In Seiple \& Salmon's (1982) study, although no audible airborne vibrations were heard, vibrations were detected using an accelerometer placed on the substratum. Airborne sounds from $S$. reticulatum were, however, recorded by Mulstay (1980). Rasping was only performed by male $S$. reticulatum during intrasexual burrow intrusion or intrasexual wandering encounters (Seiple \& Salmon 1982). In both types of encounters, the animal rasping was the winner of the encounter, regardless of whether it was the resident or intruder, initiator or responder.

To date, only one (anecdotal) observation of acoustic signalling in Perisesarma has been published. Tweedie (1954, p. 123) observed that $P$. eumolpe turned one cheliped downwards until the upper margin of the chela was approximately vertical and rubbed the upper margin of the other chela's dactylus against that of the downturned one in an up and down motion. The rubbing increased in speed, so that the active chela appeared to be almost vibrating at the end of the display. This description is similar to the acoustic displays of $P$. eumolpe observed in the present study.

Perisesarma eumolpe (De Man) and P. indiarum (Tweedie) are 2 common species in Singapore mangroves (Huang et al. 2008) that live sympatrically or allopatrically in dense aggregations on muddy substrates within mangrove tree aerial root systems (pers. obs.). They are active burrowers and have been seen to move both chelae against each other in a way that suggests stridulation (Tweedie 1954, pers. obs.). Although this behaviour does not produce any sound audible to human observers in the field, the presence of evenly spaced dactylar tubercles on the chelae suggests some form of acoustic signalling using a file-and-scraper mechanism (Tweedie 1954).

Studies on sound reception in crabs are also sparse. Internal statocysts (Cate \& Roye 1997, Fraser 2001, Lovell et al. 2005), superficial receptor systems on the body surface (Barth 1980, Budelmann 1992) and chordotonal organs (Budelmann 1992) have been identified as sound receptors, with the latter being the most studied (Barth 1934, Burke 1954, Salmon \& Atsaides 1969, Horch 1971, 1975, Salmon et al. 1977). Chordotonal organs are generally associated with joints of flexible body appendages and have connections to the central nervous system via receptor cells embedded in muscle, apodeme (internal projections of the exoskeleton) or connective tissue (Bush \& Laverack 1982). Depending on organ structure, these receptors can signal joint position, movement and tension. They can also respond to vibrations (Budelmann 1992).

The present study aims to describe the mechanisms for sound production and sound reception in Perisesarma eumolpe and $P$. indiarum, and to quantify the properties of the acoustical signals produced by these 2 species.

\section{MATERIALS AND METHODS}

Specimen collection. Crab specimens were collected by hand at low tide from September 2006 to January 2007 at Mandai Kechil mangroves $\left(1^{\circ} 26^{\prime} \mathrm{N}\right.$, $103^{\circ} 45^{\prime}$ E) in Singapore. Individual crabs were placed in plastic tanks $(30 \times 18 \times 18 \mathrm{~cm})$ and kept in outdoor laboratory conditions. The bottoms of the tanks were perforated, covered with plankton net and filled with mangrove mud to $3 \mathrm{~cm}$ depth. The tanks were then placed in larger aquaria containing seawater to maintain mud moisture and reduce accumulation of toxins. Wood debris was placed in each tank. Crabs were fed with Avicennia spp. leaves ad libitum, following known leaf feeding preferences (Boon et al. 2008).

Morphological studies. Live specimens of both species were examined by light microscopy for differences in stridulatory organs, in particular the number and structure of the chelae dactylar tubercle and rows of setae on the propodus. For a more detailed comparison, the plectrum and pars stridens were dissected and micrographed with a scanning electron microscope (SEM).

The external anatomy of the sound receptor in Perisesarma has not been described previously. Several legs of each species were dissected and SEM micrographs taken. Identification of the organ was based on SEM micrographs in Salmon et al. (1977). All dissections for SEM were made from crabs preserved in $70 \%$ alcohol and cleaned for $15 \mathrm{~min}$ in an ultrasonic bath. These samples were micrographed at magnifications of 35 to $100 \times$.

Acoustic recordings. In order to exclude background noise of the natural environment, all recordings were made in a vibration-proof laboratory. Ambient temperature was fixed at $21.5^{\circ} \mathrm{C}$. Mono channel audio recordings were obtained using a Sennheiser System K6 ME67 super-cardioid shotgun condenser microphone (frequency response $=40$ to $20000 \mathrm{~Hz}$ ) with a Marantz Professional Solid State Recorder (model PMD660). Simultaneous video recordings were made with either a Sony digital video tape camcorder or a JVC Everio HDD camcorder and the interaction arena was illuminated with a $60 \mathrm{~W}$ fluorescent bulb.

For each trial, an individual crab was first left in the plastic tank for $3 \mathrm{~d}$ to allow it to establish territory. The 
tank was then transferred to the vibration-proof laboratory where a second individual of the same species was introduced, with care taken to ensure it was a distance away from the resident crab during introduction. Recordings were carried out without human presence for 30 min after the time of the second crab's introduction. If no sound production was recorded during the $30 \mathrm{~min}$, the observation was terminated. Owing to limited availability of crabs, individuals were used more than once, either as intruder or owner, but paired with different crabs. Crabs were involved in a maximum of 3 interactions, with at least $1 \mathrm{~d}$ between observations, and no individual was paired with a previous opponent. To improve independence for subsequent statistical analyses, replicates were chosen randomly from the final dataset.

As preliminary trials demonstrated that there was no rasping in female-female or female-male interactions, only male-male interactions were studied. Spectrogram analysis using Raven Lite (version 1.0) was carried out on 33 independent replicates (i.e. different crabs), with 15 individuals of Perisesarma eumolpe and 18 individuals of $P$. indiarum.

Analysis of acoustic signals. Stridulating crabs sometimes displayed acoustically more than once in each 30 min recording. To prevent any possible confounding effects of persistence (for example, fatigue from displaying more than once which could affect number and duration of rasps), only the first display in each recording was analysed. The spectrographic analysis suggested that the signal structure could be categorized into 2 main sections: rasp train and rasp series. For rasp train, only one signal parameter was measured: rasp train rate, i.e. the number of pulses per second. Frequencies of pulses and rasp train duration were omitted due to lack of clarity in the spectrograms. More signal parameters were measured for rasp series: number of rasps, rasp rate (rasps $10 \mathrm{~s}^{-1}$ ) and frequency for each integral tap (kHz). The maximum frequency of each bout of pure stridulation in the rasp $(\mathrm{kHz})$ was also recorded, but only for Perisesarma eumolpe, as this component was usually absent or unclear in recordings of $P$. indiarum. Terminology of stridulation elements is modified from Clayton (2001) and Bennet-Clark (1998).

The signal structure of the 2 species was compared by performing MANOVA on 6 signal elements: rasp train rate, rasp series rate, number of rasps, maximum tap frequency, minimum tap frequency and mean tap frequency (described in detail in 'Results'). These elements were then separately compared using ANOVA. Statistica was used for all analyses. Box's M-test indicated homogeneous variances and Kolmogorov-Smirnov tests showed that (after log-transforming number of rasps) data for all elements other than number of rasps were distributed normally.

\section{RESULTS}

\section{Stridulatory organs}

The stridulatory structures of both Perisesarma species identified in the present study are found on the dorsal surface of the chelae. The pars stridens is composed of the tubercles on the dactylus and the plectrum is the double row of setae on the propodus (Fig. 1). No stridulatory handedness was observed for either species; approximately equal numbers of crabs stridulated with right and left claws during instances of singular display, while some crabs that displayed more than once in a single recording alternated the claw they stridulated with. Micrographs show wear lines on the tubercles, apparently resulting from friction against the setae (Fig. 2). Such wear lines are absent in the tubercles of females of both Perisesarma species, which also possess few developed setae. There are major differences between the stridulatory structures of $P$. eumolpe and $P$. indiarum (Fig. 1), e.g. the number of tubercles in the pars stridens is 17 to $21(\mathrm{n}=18)$ for $P$. eumolpe and 8 to $12(\mathrm{n}=15)$ for $P$. indiarum. The shape of the tubercles also differs: $P$. eumolpe tubercles each have a distinct depression, which is absent in
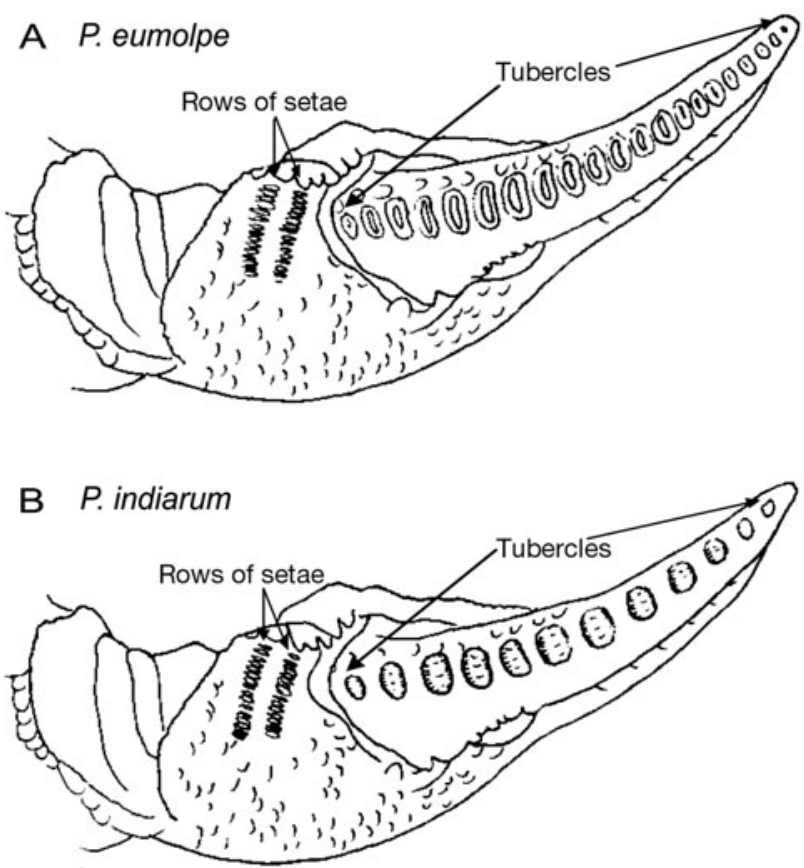

Fig. 1. Perisesarma eumolpe and $P$. indiarum. Tubercles (pars stridens) are on upper surface of dactylus and the 2 rows of setae (plectrum) are on the propodus in both (A) $P$. eumolpe and (B) P. indiarum. Approximate length of chelae as illustrated for both species is $2 \mathrm{~cm}$. Modified from figures in Gillikin \& Schubart (2004) 

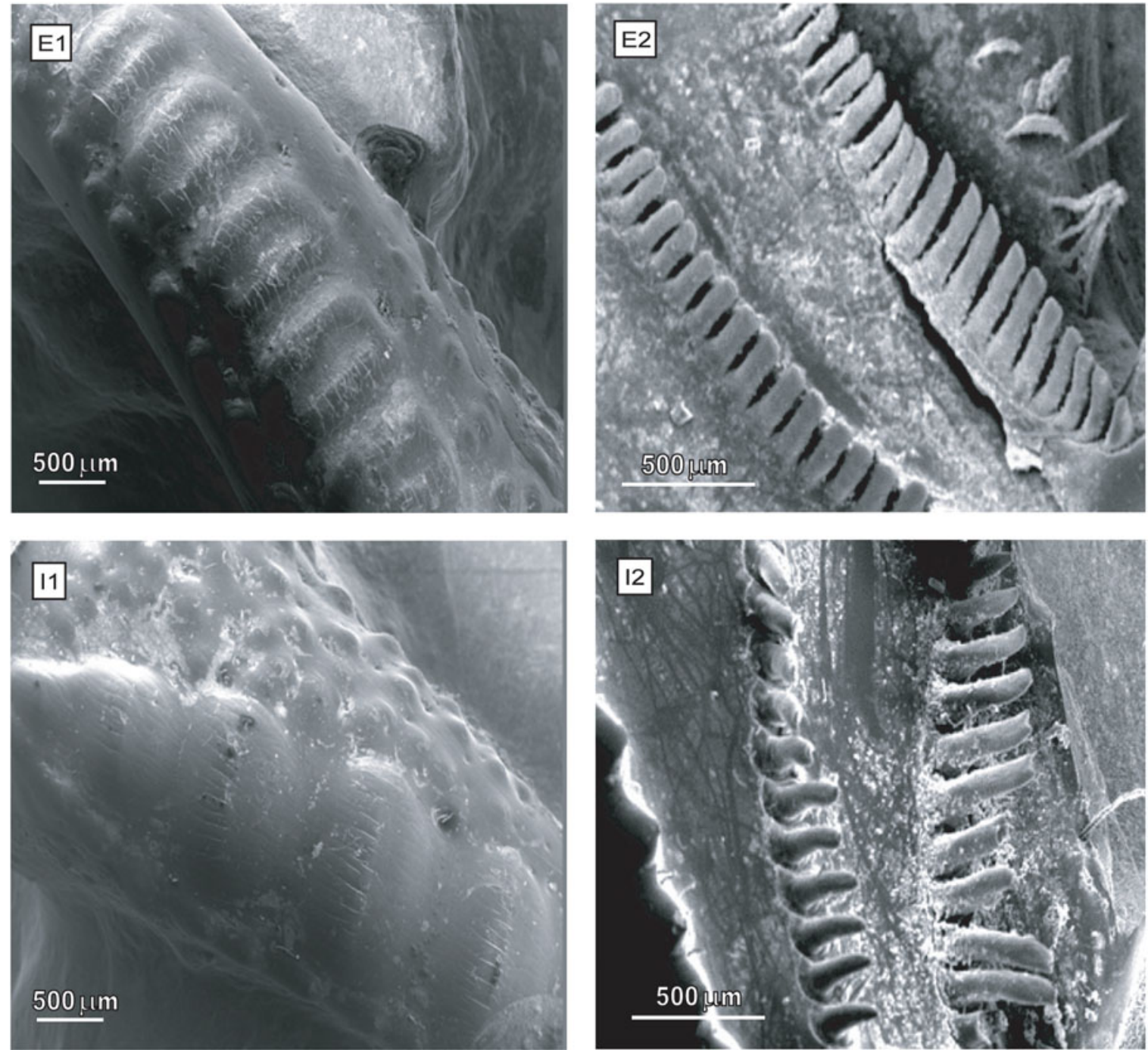

Fig. 2. Perisesarma eumolpe and P. indiarum. SEM photos of stridulatory organs in male specimens of Perisesarma. Tuberculation pattern in (E1) $P$. eumolpe and (I1) $P$. indiarum; 2 rows of setae in (E2) $P$. eumolpe and (I2) $P$. indiarum. The tips of the setae are pointing towards the distal end of the chela

$P$. indiarum. Additionally, the number of setae in the distal and proximal rows of the plectrum is 16 to $24(\mathrm{n}=$ 12) and 11 to $25(\mathrm{n}=12)$, respectively, for $P$. eumolpe, and 11 to $19(\mathrm{n}=13)$ and 7 to $16(\mathrm{n}=13)$, respectively, for $P$. indiarum.

\section{Stridulatory movements}

In both species, prior to producing a sound, the crab stops moving, elevates the front of its body and positions one of the chelae medially so that the tips of the claw are directed ventrally and touching the substrate. This claw is held stationary and its plectrum is struck by the pars stridens of the contralateral claw during rasping. As this claw is being oriented, the rasping chela correspondingly moves medially and is similarly pointed toward the substrate. A rasp train (Fig. 3, arrow A) is produced as the tubercles (pars stridens) on the dorsal ridge of the rasping claw are moved up and down repeatedly, rubbing against the 2 rows of setae (plectrum) on the propodus of the stationary contralateral claw (Fig. 4, positions A1 and A2). It is possible that the downstroke is created by the tubercles striking the proximal row of setae while the upstroke is created by striking the distal row of the dactylus. Each sound pulse in the rasp train is produced by a single up or down movement of successive impacts of the plectrum on the pars stridens teeth; each rasp train pulse consists of coherent sub-pulses, each produced by impact from a single tubercle. 

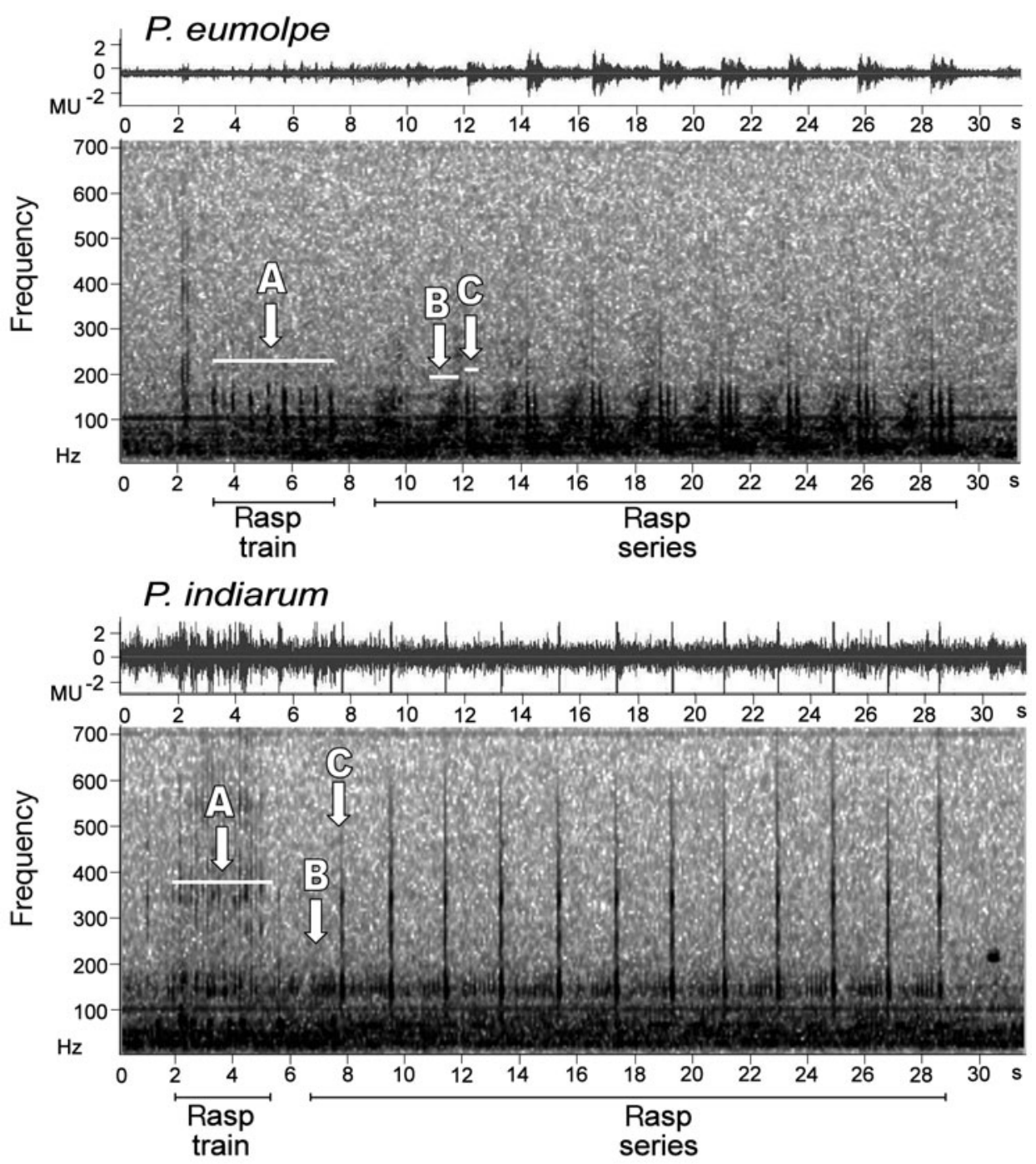

Fig. 3. Perisesarma eumolpe and $P$. indiarum. Waveform and spectrogram of $P$. eumolpe and $P$. indiarum. Each signal comprises a rasp train (A) and a rasp series, the latter of which has 2 components: pure stridulation (B) and integral tap elements (C). MU: 1 million Raven amplitude units, where $\mathrm{U}$ is the smallest amount of sound the digital recording can represent. $P$. eumolpe used for recording was an intruder (carapace width $=19.6 \mathrm{~cm}$ ) while $P$. indiarum was a resident (carapace width $=22.9 \mathrm{~cm}$ )

Production of a rasp series (Fig. 3) involves a very different mechanism. An upward stroke of the rasping claw brings the distal end of its dactylar tubercle row towards the rows of setae on the propodus of the other claw (Fig. 4, position B to position C). It is this upward stroke of the pars stridens moving against the grain of setae (Fig. 2) that produces pure stridulation (Fig. 3, arrow B). This is a train of transients similar to each sound pulse in the rasp train, only it is produced by slower movement, giving prolonged stridulation. Like the sub-pulses of each rasp train pulse, every transient of a rasp series is produced by a single tooth impact. The subsequent strike of the rasping claw's distal end of the dactylar tubercle row on the plectrum of the stationary claw (Fig. 4, position C) produces the integral tap element (Fig. 3, arrow C).

\section{Context of stridulation}

A typical encounter begins with an initial slow or fast approach by one of the males (Level 1 contest). If the contest continues, either animal may leg touch with the other (Level 2 contest). If neither animal retreats, a transition to aggressive acts involving physical contact occurs. There may be a retreat following a single claw tap (Level 3 contest) or one or both animals may rise high on their ambulatories and lean posteriorly while open fingers of the chelipeds interlock and a series of pushes follow until one animal breaks away (Level 4 contest). In the final level of escalation, the claw interlock can be interspersed with claw taps or combatants extending claws to tap or touch the face of the opponent. Threat displays of chelae shielding are also often 

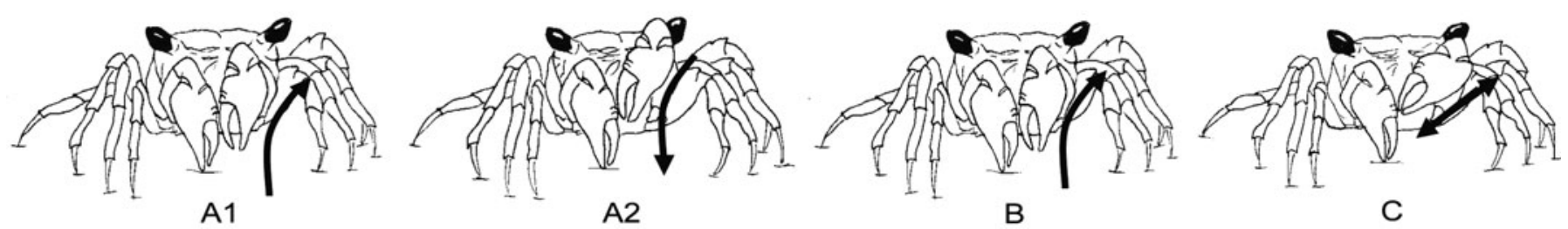

Fig. 4. Perisesarma eumolpe and P. indiarum. Movement of the chelae during sound production. The sounds these movements elicit are shown in Fig 3. Arrows indicate the direction of chela movement with the pars stridens on its dactylus. The production of a rasp train (Fig 3, arrow A) starts with position A1, where both chelae are directed medially and tip down. One claw remains stationary while the rasping claw is moved up and down repeatedly, changing between positions A1 and A2. The production of a rasp series starts with position $\mathrm{B}$, and the upward stroke of the rasping claw to reach position C gives the pure stridulation (Fig 3 , arrow B). At position C, the tip of the rasping claw striking the rows of setae on the propodus of the stationary contralateral claw gives the integral tap element (Fig 3, arrow C). The rasping claw then moves back to position B and another rasp is produced again (pure stridulation followed by integral tap element) to give a series of rasps

observed after a level 4 contest. Several all-out fights were also observed ( $P$. eumolpe: $\mathrm{n}=4 ;$. indiarum: $\mathrm{n}=$ 6 ) in which seemingly costly behaviour such as claw tapping and claw interlocking did not unambiguously escalate from initial low cost behaviours such as noncontact approaches or leg touching.

The context in which stridulation occurred for both species was similar, with most instances observed after contact interactions (contest levels 2 to 4 ). Level 4 contests had the highest percentage of occurrences (Perisesarma eumolpe $=45.45 \%$; $P$. indiarum $=56.52 \%$ ).

All acoustic displays were unilateral interactions with only one crab displaying at a time. Both resident and intruder crabs displayed, with the higher percentage of displaying crabs being residents (Perisesarma eumolpe $=61 \% ; P$. indiarum $=75 \%$ ). The size of the stridulating crabs ranged from 17.3 to $23.0 \mathrm{~mm}$ carapace width for $P$. eumolpe and 20.0 to $24.3 \mathrm{~mm}$ carapace width for $P$. indiarum. Among the displaying intruders, a higher percentage were larger than the resident $(P$. eumolpe $=73 \%$; $P$. indiarum $=80 \%)$. Crabs always performed the entire set of acoustic display components starting with the rasp train and ending with a series of rasps. Crabs performed a truncated display set on only 2 occasions, and this was in reaction to an approaching opponent initiating a fight (claw push or claw interlock). The opponent did not adopt any particular consistent posture during rival stridulation.

\section{Interspecific variation in acoustic signals}

The basic stridulation movements are the same between the 2 species, but there exist intrinsic differences in sound production that give rise to corresponding differences in signal parameters. Firstly, Perisesarma indiarum consistently produced signals with only a single integral tap element while $P$. eumolpe had 2 to 4 integral tap elements for each series pulse (Fig. 3, see Fig. 7). This is due to the higher number of strikes of the moving claw's distal end of the dactylar tubercle row on the contralateral claw after each pure stridulation (Fig. 4, position B).

Pure stridulation in the spectrogram analysis of Perisesarma indiarum signals was not always clear, but the better quality spectrographs suggest a near constant frequency, while in $P$. eumolpe, pure stridulation increased from low to higher frequency just before integral taps. This could perhaps be attributed to the differences in stridulatory organ morphology as described above. As the number of ridges in an individual is fixed, frequency increase could also be due to an acceleration of speed during the upward stroke of the moving chela (Clayton 2001).

During production of the rasp train (made up of train pulses), up-down movement of the pars stridens of Perisesarma eumolpe was much slower than that of $P$. indiarum (see Table 1), which can sometimes be updown-down, with the downstroke being 2 distinct movements. There was a significant difference between the signal qualities of the 2 species (MANOVA, Wilks' lambda $=0.258$, Rao's $\mathrm{R}=9.119, \mathrm{df}=6,19, \mathrm{p}<0.001$ ), and rasp train rate (ANOVA, $\mathrm{p}<0.001$ ) and rasp series rate (ANOVA, $p<0.05$ ) were significantly different. Duration of each acoustic display lasted from 10.5 to $31.6 \mathrm{~s}$ in $P$. eumolpe and from 7.2 to $25.5 \mathrm{~s}$ in $P$. indiarum. A summary of all the signal parameters is provided in Fig. 5.

\section{Sound reception (Barth's organ)}

Barth's organ was found on the underside of the meral-ischial joint (Fig. 6) in both male (Fig. 7) and female Perisesarma eumolpe and P. indiarum. Similar to the external anatomy of Barth's organ in fiddler crabs (Salmon et al. 1977), the organ in Perisesarma could also be easily identified by its thin-walled window. The window is distinguished by a centre bulging outwards from a surrounding depression. 


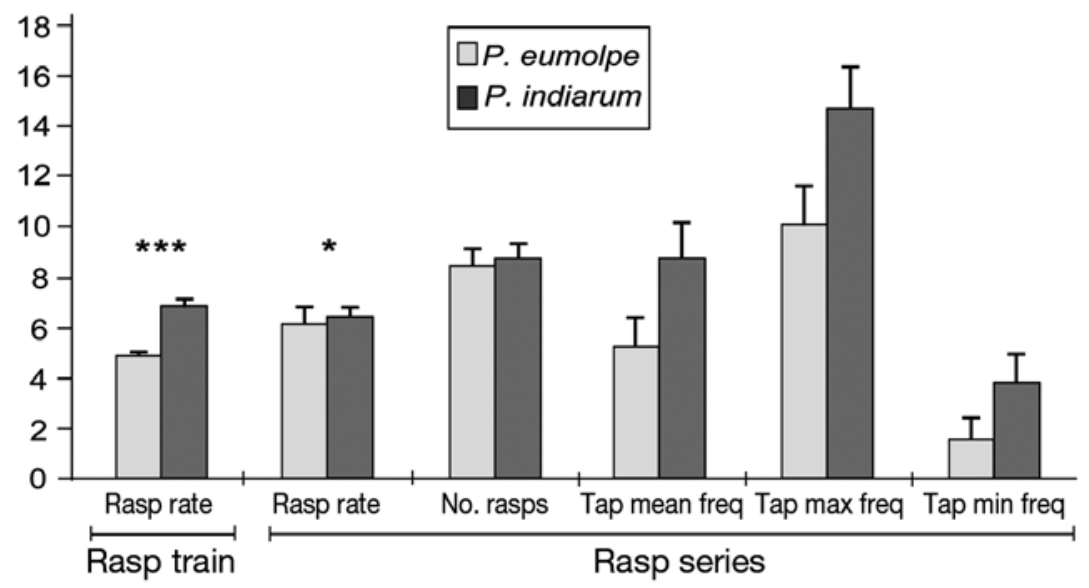

Fig. 5. Perisesarma eumolpe and $P$. indiarum. Signal elements (mean $\pm \mathrm{SE}$ ) of $P$. eumolpe and $P$. indiarum. Rasp train rate in pulses $\mathrm{s}^{-1}$; rasp series rate in pulses $10 \mathrm{~s}^{-1}$; frequency in $\mathrm{kHz}$. Differences between species, as revealed by ANOVA, are indicated above each column. ${ }^{*} \mathrm{p}<0.05{ }^{* * *} \mathrm{p}<0.001$. P. eumolpe: $\mathrm{n}=15$, P. indiarum: $\mathrm{n}=18$
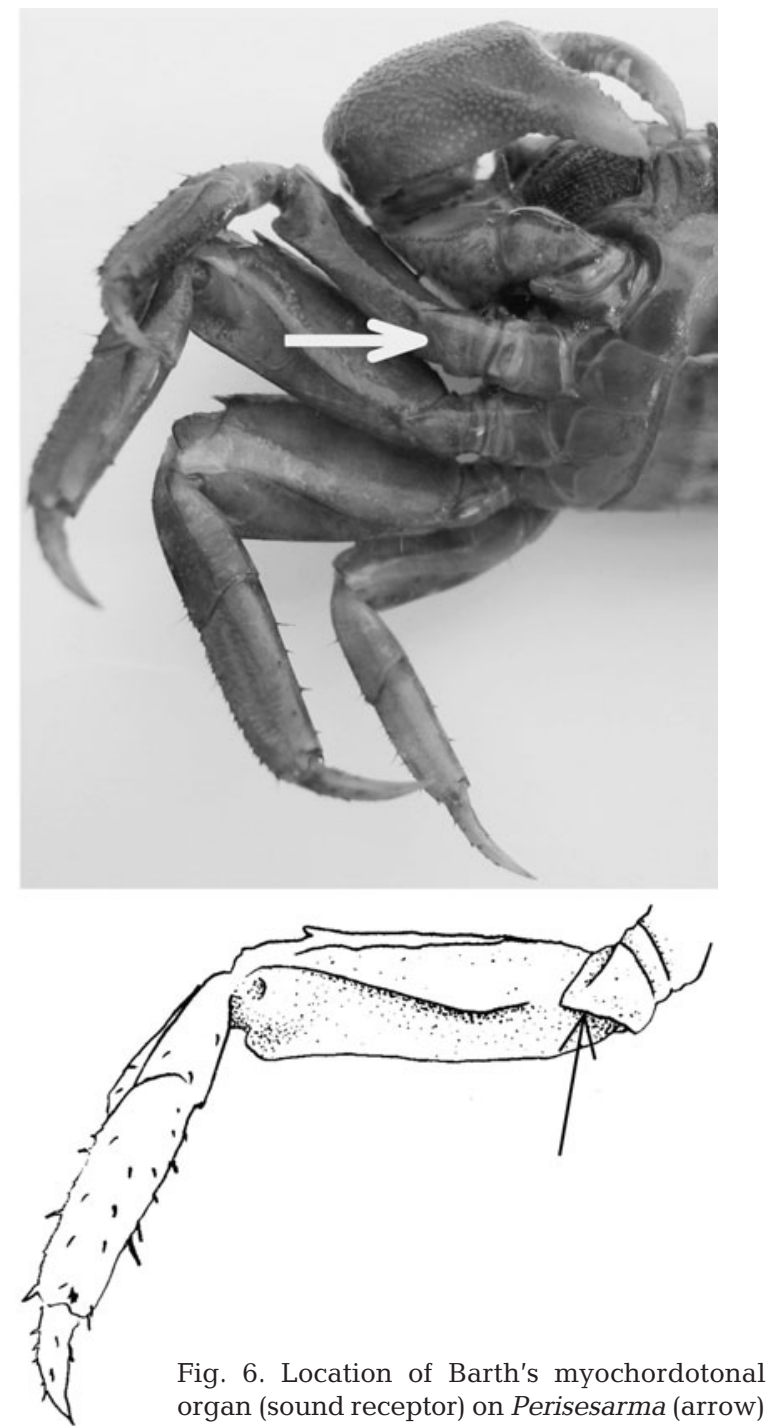

\section{DISCUSSION}

Decapod crustaceans possess a wide variety of morphological features that could potentially generate auditory signals (Guinot-Dumortier \& Dumortier 1960). The 2 primary modes of stridulation are believed to be friction of appendages against the cephalothorax or friction of appendages against other appendages (Guinot-Dumortier \& Dumortier 1960). Actual observations of stridulation, however, have only been reported for a dozen or so species. For both Perisesarma species examined here, the movement and positioning of the 2 chelae while rubbing against each other match the brief descriptions of stridulation reported for $P$. eumolpe by Tweedie (1954) and $S$. reticulatum by Seiple \& Salmon (1982) and Mulstay (1980). Contrary to how the stridulatory apparatus was previously thought to work, i.e. 2 rows of dactylar tubercles on separate claws rubbing against each other (Tweedie 1954), we observed in the present study dactylar tubercles (pars stridens) on the chela moving against 2 rows of setae (plectrum) on the stationary contralateral chela.

In sesarmids, the 'peculiar and consistent feature' of setae rows on the propodus have long been noted by taxonomists, but their biological significance was unknown (Tweedie 1954, p. 125). Tweedie (1954) predicted that they have a sensory function, given that they are only present in sesarmid species that have developed dactylar tubercles such as Sesarma johorensis and S. moeschii, but not in S. fasciata where tubercles are absent (Tweedie 1954). The present study's findings indicate that the rows of setae are, in fact, part of the stridulatory apparatus.

Motor movements during sound production for Perisesarma are similar to those reported by Mulstay (1980) for Sesarma reticulatum, the closest species to Perisesarma in which acoustic signals have been recorded. Mulstay (1980), however, observed that for $S$. reticulatum, the claw usually does not touch the substrate unless the crab's movements are restricted within a burrow. In contrast, both $P$. eumolpe and $P$. indiarum have the stationary chela in contact with the substrate during stridulation. The number of rasps and rasp interval were both lower in $P$. eumolpe and $P$. indiarum than in $S$. reticulatum (Table 1, Mulstay 1980). Frequency comparisons were not possible due to a lack of frequency data for $S$. reticulatum-only one oscillograph was reported in the literature (Mulstay 1980). Of the 2 species studied here, $P$. indiarum is 

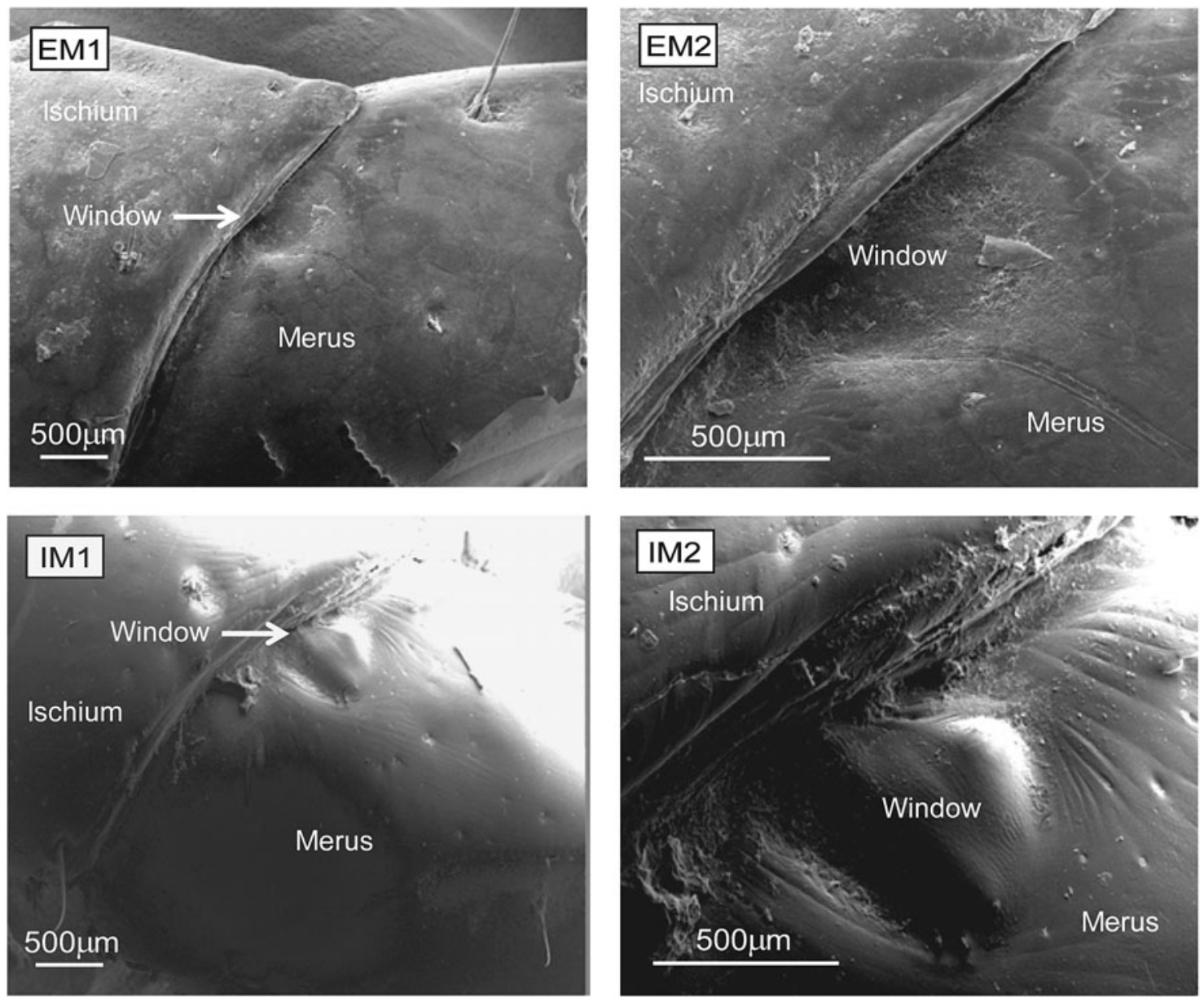

Fig. 7. Perisesarma eumolpe and P. indiarum. Scanning electron microscope (SEM) images showing the external anatomy of Barth's organ in a male $P$. eumolpe (EM1, EM2) and a male $P$. indiarum (IM1, IM2). EM1 and EM2 show the underside of meral-ischial joint, with a white arrow showing a triangular depression of exoskeleton in the merus $(\times 35)$. EM2 and IM2 show an enlarged view of Barth's organ $(\times 100)$. Window: window of Barth's organ

more similar in the sounds it produces to S. reticulatum, with only one integral tap per individual rasp compared to 3 or more integral taps for $P$. eumolpe.

Rasp series of Perisesarma are similar to those of the ghost crabs Ocypode jousseaumei and O. rotundata. Individual rasps with pure stridulation and an integral broadband element are found in both species (Clayton 2001). This is interesting given the different stridulatory apparatus of the 2 crabs: Perisesarma rub a row of

Table 1. Signal parameters of Perisesarma eumolpe, P. indiarum and Sesarma reticulatum. Data of $S$. reticulatum taken from Mulstay (1980)

\begin{tabular}{|lcccc|} 
& \multicolumn{2}{c}{ No. rasps } & \multicolumn{2}{c|}{ Rasp interval (ms) } \\
& Mean \pm SE & Range & Mean \pm SE & Range \\
\hline P. eumolpe & $8.50 \pm 1.32$ & $5-16$ & $2.27 \pm 0.13$ & $1.77-2.91$ \\
$P$. indiarum & $8.73 \pm 0.59$ & $5-14$ & $1.94 \pm 0.10$ & $0.97-2.52$ \\
S. reticulatum & $17.5 \pm 0.26$ & $6-29$ & $3.4 \pm 0.02$ & $2.7-4.2$ \\
\hline
\end{tabular}

tubercles of one claw against setae of another claw, while ghost crabs rub a row of denticulations on the inner face of the major chela across an ischial ridge on the same claw (Clayton 2001). The integral broadband elements of ghost crabs and Perisesarma are also produced differently. For Perisesarma, the integral tap element is produced by striking the distal end of the dactylus of the moving claw against the propodus of the stationary contralateral claw, whereas $O$. jousseaumei and $O$. rotundata produce the integral rap element by the rapid forward movement of chela against the side of burrow. While this integral broadband element is a consistent feature in Perisesarma sounds, this is not so for Ocypode; furthermore, the sequence of sound elements in each bout of display is more varied in Ocypode spp. Rather than the fixed order of a rasp train before one rasp series 
found in Perisesarma, Ocypode do not produce a rasp train, and several rasp series are made during each bout of display, each consisting of a varying number of rasps (Clayton 2001). The number of rasps per rasp series in Ocypode spp. is also lower than in Perisesarma (data of $O$. jousseaumei, O. platytarsus and $O$. ceraptophthalmus taken from Clayton 2001).

The body plan of decapod crustaceans and its corresponding constraints on sensory structures limit the reception of acoustic stimuli in decapods to particle displacement components of an impinging sound field (Budelmann 1992, Popper et al. 2001). Three main groups of receptor systems are involved in the reception of sound in Crustacea: internal statocyst receptor systems (Fraser 2001, Lovell et al. 2005), superficial receptor systems on the body surface and chordotonal organs (Budelmann 1992). In some semiterrestrial crabs, the meral segment of each walking leg possesses a Barth's myochordotonal organ-a structure known to detect acoustic stimuli (Barth 1934, Horch 1971, 1975, Salmon et al. 1977). In ghost crabs, this receptor is equally sensitive to both substrate-borne and airborne sound (Horch 1971) while in fiddler crabs it responds primarily to substrate-borne energies (Salmon et al. 1977).

Barth's organ in Perisesarma is very similar morphologically to that of UCa spp. (M. Salmon pers. comm.). Functionally, Barth's organ has been shown in Ocypodidae to increase sensitivity to those frequencies above predominant background noise but below higher frequencies that attenuate rapidly with distance (Popper et al. 2001). This could also be the case for Perisesarma. The window could function by receiving vibrations carried through the leg exoskeleton (Horch 1971) or it may also act as a tympanum in response to airborne sounds (Salmon et al. 1977).

In Perisesarma eumolpe and P. indiarum, the stationary chelae is in contact with the substrate during rasping, and this could provide a route for vibrations produced to be effectively transmitted to the ground. Moreover, the low frequencies of Perisesarma sounds are characteristic of vibrational signals (Cocroft \& Rodríguez 2005). Further work is required to determine whether airborne and/or substrate-borne signals are used for communication in these crabs.

Acknowledgements. We thank A. C. Diesmos and D. Bickford for the loan of audio recording equipment and guidance in use of Raven; B. Tan for use of the Acoustics Laboratory at the Physics Department, National University of Singapore; G. L. Loy, who provided support with the scanning electron microscope; M. Salmon, who helped to identify Barth's organ; B. Ritcher De Forges for his advice; and all the people who assisted in the collection of specimens. We also thank 3 anonymous reviewers whose comments helped to improve the manuscript. This study was supported by the Department of Biological Sciences, National University of Singapore.

\section{LITERATURE CITED}

Barth FG (1934) Untersuchungen über Myochordotonalorgane bei Dekapoden. Crustaceen. Z Wiss Zool 145:576-624

Barth FG (1980) Campniform sensilla: another vibration receptor in the crab leg. Naturwissenschaften 67:201-202

> Bennet-Clark HC (1998) Size and scale effects as constraints in insect sound communication. Philos Trans R Soc Lond B Biol Sci 353:407-419

Boon PY, Yeo DCJ, Todd PA (2008) Feeding ecology of two species of Perisesarma (Crustacea: Decapoda: Brachyura: Sesarmidae) in Mandai mangroves, Singapore. J Crustac Biol 28:480-484

Budelmann BU (1992) Hearing in Crustacea. In: Webster DB, Fay RR, Popper AN (eds) The evolutionary biology of hearing. Springer-Verlag, Berlin, p 131-139

Burke W (1954) An organ for proprioception and vibration sense in Carcinus maenas. J Exp Biol 31:127-138

Bush BMH, Laverack MS (1982) Mechanoreception. In: Atwood HL, Sandeman DC (eds) The biology of Crustacea, Vol. 3. Neurobiology: structure and function. Academic Press, New York, p 399-468

Cate HS, Roye DB (1997) Ultrastructure and physiology of the outer row statolith sensilla of the blue crab, Callinectes sapidus. J Crustac Biol 17:398-411

Clayton D (2001) Acoustic calling in four species of ghost crabs: Ocypode jousseaumei, O. platytarsus, O. rotundata and $O$. saratan (Brachyura: Ocypodidae). Bioacoustics 12:37-55

> Clayton D (2005) Substrate (acoustic/vibrational) communication and ecology of the ghost crab Ocypode jousseaumei (Brachyura: Ocypodidae). Mar Freshw Behav Physiol 38: $53-70$

Cocroft RB, Rodríguez RL (2005) The behavioral ecology of insect vibrational communication. Bioscience 55:323-334

Crane J (1966) Combat, display and ritualization in fiddler crabs (Ocypodidae, Genus Uca). Philos Trans R Soc Lond B Biol Sci 251:459-472

Dumortier B (1963) Morphology of sound emission apparatus in Arthropoda. In: Busnel RG (ed) Acoustic behavior of animals. Elsevier, New York

> Fraser PJ (2001) Statocysts in crabs: short-term control of locomotion and long-term monitoring of hydrostatic pressure. Biol Bull 200:155-159

Gillikin DP, Schubart CD (2004) Ecology and systematics of mangrove crabs of the genus Perisesarma (Crustacea: Brachyura: Sesarmidae) from East Africa. Zool J Linn Soc 141:435-445

> Guinot-Dumortier D, Dumortier B (1960) La stridulation chez les crabes. Crustaceana 1:117-155

> Horch K (1971) An organ for hearing and vibration sense in the ghost crab, Ocypode. Z Vgl Physiol 73:1-21

Horch K (1975) The acoustic behaviour of the ghost crab Ocypode cordimana Latreielle, 1818 (Decapoda, Brachyura). Crustaceana 29:193-204

Horch K, Salmon M (1969) Production, perception and reception of acoustic stimuli by semi-terrestrial crabs (Genus Ocypode and Uca, family Ocypodidae). Forma Functio $1: 1-25$

> Huang H, Todd PA, Yeo DCJ (2008) Inter- and intraspecific variations in the facial colours of mangrove Perisesarma crabs (Crustacea: Brachyura: Sesarmidae). Hydrobiologia 598:361-371

> Lee SY (1998) Ecological role of grapsid crabs in mangrove ecosystems: a review. Mar Freshw Res 49:335-343

Lovell JM, Findlay MM, Moate RM, Yan HY (2005) The hearing abilities of the prawn Palaemon serratus. Comp Biochem Physiol A 140:89-100 
Mulstay RE (1980) Acoustic behavior in the purple marsh crab, Sesarma reticulatum Say (Decapoda, Grapsidae). Crustaceana 39:301-305

Ortmann AE (1901) Die Klassen und Ordnungen der Arthropoden. In: Bronn HG (ed) Klassen und Ordnungen des Thier-Reichs, Vol 5, II: Malacostraca. Wintersche Verlagsbuchhandlung, Leipzig

Popper AN, Salmon M, Horch KW (2001) Acoustic detection and communication by decapod crustaceans. J Comp Physiol A 187:83-89

Salmon M (1965) Waving display and sound production in the courtship behavior of Uca pugilator, with comparisons to $U$. minax and U. pugnax. Zoologica 50:123-149

Salmon M (1967) Coastal distribution, display and sound production by Florida fiddler crabs (genus Uca). Anim Behav 15:449-459

Salmon M, Atsaides SP (1968) Visual and acoustical signalling during courtship by fiddler crabs (Genus Uca). Am Zool 8:623-639

Salmon M, Atsaides SP (1969) Sensitivity to substrate vibration in the fiddler crab, Uca pugilator Bosc. Anim Behav 17:68-76

Salmon M, Horch K (1972) Acoustic signalling and detection

Editorial responsibility: David Fields,

West Boothbay Harbor, Maine, USA by semi-terrestrial crabs of the family Ocypodidae. In: Winn HE, Olla B (eds) Recent advances in the behaviour of marine organisms. Plenum Press, New York, p 60-96

Salmon M, Horch K, Hyatt GW (1977) Barth's myochordotonal organ as a receptor for auditory and vibrational stimuli in fiddler crabs (Uca pugilator and U. minax). Mar Behav Physiol 4:187-194

Schöne H (1968) Agonistic and sexual display in aquatic and semi-terrestrial brachyuran crabs. Am Zool 8:641-654

Seiple W, Salmon M (1982) Comparative social behaviour of two grapsid crabs, Sesarma reticulatum (Say) and $S$. cinereum (Bosc). J Exp Mar Biol Ecol 62:1-24

Smith TJ III, Boto KG, Frusher SD, Giddins RL (1991) Keystone species and mangrove forest dynamics: the influence of burrowing crabs on soil nutrient status and forest productivity. Estuar Coast Shelf Sci 33:419-432

Tweedie MWF (1954) Notes on the grapsoid crabs from the Raffles Museum, nos. 3, 4 and 5. Bull Raffles Mus 25: $118-128$

von Hagen HO (1975) Klassifikation und phylogenetische Einordnung der Lautäußerungen von Ocypodiden und Grapsiden (Crustacea, Brachyura). Z Zool Syst Evolforsch 13:300-316

Submitted: July 3, 2008; Accepted: December 16, 2008

Proofs received from author(s): February 24, 2009 